\title{
GASTROESOPHAGEAL REFLUX DISEASE AND VOCAL DISTURBANCES
}

\author{
Maria Aparecida Coelho de Arruda HENRY'1, Regina Helena Garcia MARTINS², \\ Mauro Masson LERCO ${ }^{1}$, Lídia Raquel CARVALHO ${ }^{3}$ and Vânia Cristina LAMÔNICA-GARCIA ${ }^{4}$
}

\begin{abstract}
Context - Gastroesophageal reflux disease is a chronic disease in which gastroduodenal contents reflux into the esophagus. The clinical picture of gastroesophageal reflux disease is usually composed by heartburn and regurgitation (typical manifestations). Atypical manifestations (vocal disturbances and asthma) may also be complaint. Objective - To analyse the clinical, endoscopic, manometric and pHmetric aspects of patients suffering from gastroesophageal reflux disease associated with vocal disturbances. Methods - Fifty patients with gastroesophageal reflux disease were studied, including 25 with vocal disturbances (group 1 - G1) and 25 without these symptoms (group $2-$ G2). All patients were submitted to endoscopy, manometry and esophageal pHmetry (2 probes). The group 1 patients were submitted to videolaryngoscopy. Results - Endoscopic findings: non-erosive reflux disease was observed in $95 \%$ of G1 patients and $88 \%$ of G2. Videolaryngoscopy: vocal fold congestion, asymmetry, nodules and polyps were observed in G1 patients. Manometric findings: pressure in the lower esophageal sphincter (mm Hg): $11.6 \pm 5.2$ in G1 and $14.0 \pm 6.2$ in $\mathrm{G} 2(P=0.14)$; pressure in the upper esophageal sphincter $(\mathrm{mm} \mathrm{Hg}): 58.4 \pm 15.9$ in $\mathrm{G} 1$ and $69.5 \pm 30.7$ in the controls. pHmetric findings: De Meester index: $34.0 \pm 20.9$ in G1 and $15.4 \pm 9.4$ in G2 $(P<0.001)$; number of reflux episodes in distal probe: $43.0 \pm 20.4$ in $\mathrm{G} 1$ and $26.4 \pm 17.2$ in G2 $(P=0.003)$; percentage of time with esophageal pH value lower than 4 units (distal sensor): $9.0 \% \pm$ $6.4 \%$ in $\mathrm{G} 1$ and $3.4 \% \pm 2.1 \%$ in G2 $(P<0.001)$; number of reflux episodes in proximal probe: $7.5 \pm 10.9$ in G1 and $5.3 \pm 5.7$ in G2 $(P$ $=0.38$ ); percentage of time with esophageal $\mathrm{pH}$ values lower than 4 units (proximal probe): $1.2 \pm 2.7$ in G1 and $0.5 \pm 0.7$ in G2 ( $P=$ 0.21). Conclusions - 1) The clinical, endoscopic, and manometric findings observed in patients with vocal disturbance do not differ from those without these symptoms; 2) gastroesophageal reflux intensity is higher in patients with vocal disturbance; 3) patients without vocal disturbance can also present reflux episodes in the proximal probe.
\end{abstract}

HEADINGS - Gastroesophageal reflux. Voice disorders.

\section{INTRODUCTION}

In gastroesophageal reflux disease (GERD), a high prevalence digestive affliction, the gastroduodenal contents leak back into the esophagus and can reach beyond it, go through the upper esophageal sphincter (UES) and reach the aero-digestive airways ${ }^{(4,20,28)}$. Such an episode is called laryngopharyngeal reflux ${ }^{(9,22)}$.

The larynx, an important organ responsible for phonation, can be injured in this situation, resulting in a process called acid laryngitis, described by Cherry and Margulies ${ }^{(3)}$ in 1968. The clinical manifestation is voice disorder ${ }^{(24)}$ that affect life quality as they reduce the speaker's communicative effectiveness.

Besides GERD, other factors affect the voice considerably, with the most important being smoking, drinking, voice abuse, allergy, asthma, air conditioning and addiction to drugs, especially marijuana ${ }^{(18,28,32)}$.

Two mechanisms have been mentioned in the etiopathogenesis of injured organs in the aero-digestive airways, most importantly the direct contact of refluxed material with the laryn $\mathrm{x}^{(32)}$.

According to Koufmann ${ }^{(13)}$, laryngeal epithelium is 100 times more sensitive than the esophagus. Therefore, the reflux of small amounts of gastric secretion containing hydrochloric acid, pepsin and other digestive enzymes is sufficient to cause serious lesions in the larynx ${ }^{(23)}$.

Another aspect to be considered is the fact that the larynx is practically defenseless given that its only defense mechanism is the UES. On the other hand, the esophagus has several defense mechanisms including peristalsis, the mucous barrier, bicarbonate production, and the LES ${ }^{(13)}$.

The second mechanism that produces larynx inflammatory process is chemoreceptor stimulation resulting from refluxed material from the stomach, with vagal reflexes followed by coughing and throat clearing.

The prevalence of extra esophageal manifestations related to GERD is unknown. It is estimated that $4 \%$

Department of Surgery and Orthopedics, Botucatu Medical School, São Paulo State University (UNESP).2 Department of Ophthalmology, Otorhinolaryngology and Head and Neck Surgery, UNESP; ${ }^{3}$ Department of Statistics - Institute of Biosciences, UNESP; ${ }^{4}$ Post-Graduation in Basic Surgery Program, Botucatu School of Medicine UNESP, Botucatu, SP, Brasil. Correspondence: Prof. Maria Aparecida Coelho de Arruda Henry - Rua Miguel Ciofi, 200 - Vila dos Médicos - 18607-790 - Botucatu, SP, Brasil. E-mail: rhenry@ibb.unesp.br 
to $10 \%$ of the patients that seek otorhinolaryngologic service show symptoms of this disease ${ }^{(12)}$.

This paper aimed to analyze the clinical, endoscopic, manometric and pHmetric aspects of patients with GERD and vocal disturbances and to compare them with chronic refluxers without these symptoms.

\section{METHODS}

In this retrospective survey, 50 patients with GERD divided into groups of 25 each were studied. They had the following characteristics: Group $1(\mathrm{G} 1)$ : patients with typical symptoms of GERD and vocal disturbance (hoarseness, voice failure), being 3 men and 22 women, age varying from 24 to 68 years (average $46.8 \pm 12.1$ years). Group 2 (G2): 9 men and 16 women with GERD symptoms but without dysphonia (controls), mean age $39.1 \pm 10.7$ (extremes of 15 and 54 years).

Inclusion criteria: females or males, ranging in age from 15 to 70 years, suffering from GERD with or without dysphonia (G1 and G2, respectively).

Exclusion criteria: patients under 15 and above 70 years, pregnant women, alcoholics, smokers, and individuals with systemic diseases that affect esophageal motor activity.

After the agreement of the research project by the Ethical Committee on Research from our hospital (Of. $n^{\circ}$ 020/2010), the patients from both groups were submitted to endoscopic, manometric, and pHmetric esophagus exams to confirm GERD diagnostic.

Individuals with dysphonia were submitted to pharyngolaryngoscopy, carried out by an othorhinolaryngologist, responsible of the Voice Disturbances Ambulatory. Patients from G2 (controls) did not undergo this exam based on an instruction from the Ethics Committee.

- Endoscopy

After a clinical evaluation, 10-hour fast, and oropharyngeal topical anesthetic with $10 \%$ xylocaine spray, the patients were submitted to high digestive endoscopy using Olympus flexible endoscopic video. The exam was performed with the patient in left lateral decubitus. Esophageal mucosa lesions were evaluated using Savary and Miller ${ }^{(25)}$ classification.

- Esophageal manometry

Esophageal manometry was performed using the usual technique of our laboratory ${ }^{(7)}$ which included an 8-channel probe, physiographic process and continuous infusion device. Through the analysis of the graphic records the following parameters were evaluated: lower and upper sphincter resting pressure of the esophagus (LES, UES) and its peristalsis.

- Esophageal 24-hour pH study

A pH catheter of two probes was passed transnasally into the previously anesthetized (xylocaine gel) patients after 24-hour fast and 1-week suspension of proton pump inhibitors. The patients were guided to avoid acid food and juices ingestion during the investigation. The distal probe was positioned $5 \mathrm{~cm}$ above LES, and the proximal probe near the UES. The patient was examined at home for 24 hours $^{(6,12)}$. The following parameters were evaluated: number of reflux episodes and percentage of time in which the esophageal $\mathrm{pH}$ showed values below 4 units in the two probes and the De Meester index.

- Videolaryngoscopy

The flexible device (Olympus) was introduced nasally into the patients after 12-hour fast and topic anesthesia with $10 \%$ xylocaine spray. The patient was seated. This exam permitted evaluation of vocal folds, pharynx, larynx and arytenoids (Figures 1, 2 and 3, Table 1).

- Statistical analysis

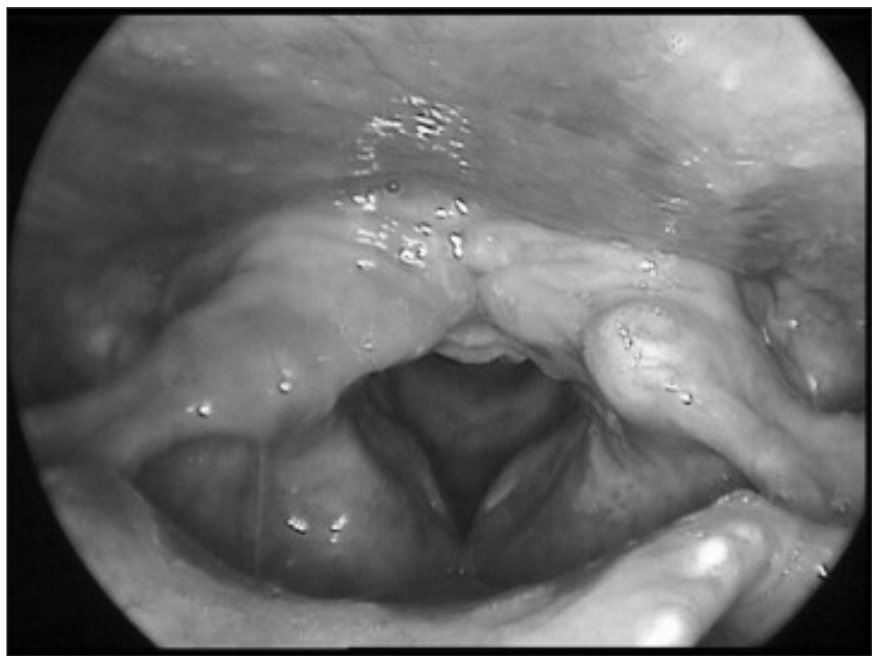

FIGURE 1. Edema, packydermia and mucosal thickening of vocal folds and posterior glottis

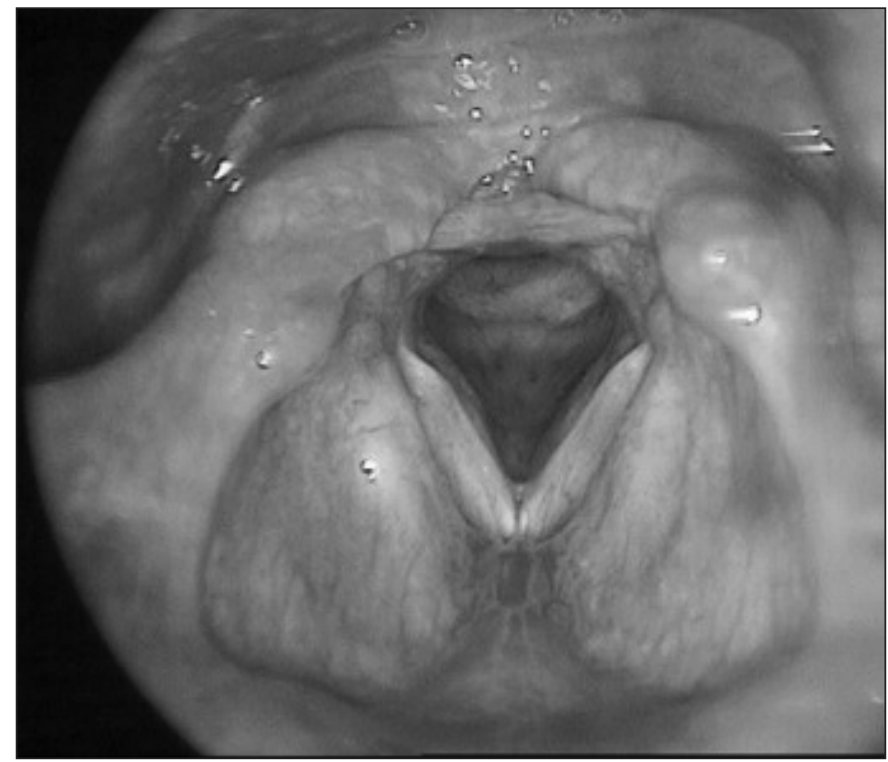

FIGURE 2. Edema in vocal fold, pachydermia inter-aritenoid 


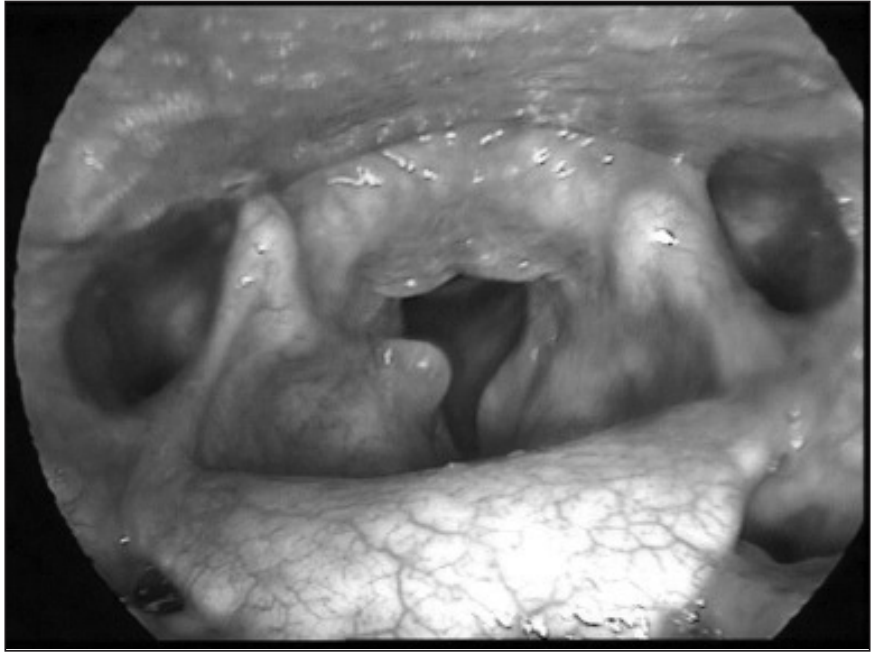

FIGURE 3. Polyp in right vocal fold; Reinke's edema in left vocal fold edema and pachydermia in posterior glottis

TABLE 1. Findings observed during pharyngolaryngoscopy

\begin{tabular}{lc}
\hline Findings & $\mathbf{n}$ \\
\hline Edema / VF congestion & 10 \\
Pachydermia - arytenoid & 6 \\
Node in VF & 5 \\
Edema in arytenoids & 4 \\
Cyst in VF & 2 \\
Atrophy in VF & 2 \\
Polyp in VF & 1 \\
Asymmetry in VF & 1 \\
\hline
\end{tabular}

To study the association between qualitative variables, the Chisquare test was used. Student $t$ test was used for comparison of the quantitative variables. The significance level was $5 \%$.

\section{RESULTS}

Hoarseness was the most frequently observed vocal disturbance among $\mathrm{G} 1$ patients and lasted between 6 months and 20 years (average $3.3 \pm 1.6$ years) followed by voice failure, referenced by 14 patients (average $1.6 \pm 3.3$ years). All G1 patients also reported pyrosis, with a mean duration of 9.1 \pm 8.5 years. In the control group pyrosis lasted an average of $7.6 \pm 6.8$ years. The two groups did not differ significantly as to pyrosis duration $(P=0.51)$ (Table 2$)$.

In relation to gender, there was a greater number of females in $\mathrm{G} 1$ than in $\mathrm{G} 2(P=0.047)$ (Table 2$)$.

High digestive endoscopy revealed similar findings in both groups. Non-erosive reflux (normal mucous relief) was observed in $95 \%$ of $\mathrm{G} 1$ patients and in $88 \%$ of G2 patients $(P=0.53 \%)$. Hiatal hernia was diagnosed in $65 \%$ of the patients with vocal disturbance and in $60 \%$ of controls $(P=0.77)$. The hiatal hernia diagnostic was validated when epithelial transition (the $\mathrm{Z}$ line) was found $2 \mathrm{~cm}$ above the diaphragmatic crura ${ }^{(25)}$. The gastric retroversion maneuver showed cardiac orifice incompetence in $70 \%$ of G1 and in $60 \%$ of G2 patients, with no significant difference $(P=0.54)$.

The esophageal motor activity was studied in all the patients. The average pressure in the LES in individuals with dysphonia was of $11.6 \pm 5.2 \mathrm{~mm} \mathrm{Hg}$, with no significant difference in relation to controls $(14.0 \pm 6.2 \mathrm{~mm} \mathrm{Hg}$; $P=0.14)$. A similar result was observed for UES with mean values of $58.4 \pm 15.9 \mathrm{~mm} \mathrm{Hg}$ for G1 and $69.5 \pm 30.7 \mathrm{~mm} \mathrm{Hg}$ for the controls. The esophageal body showed no motor

VF: vocal fold

TABLE 2. Mean and standard deviation of the studied parameters in the two groups, for clinical, manometric and pHmetric findings

\begin{tabular}{|c|c|c|c|}
\hline \multirow[b]{2}{*}{ Parameter } & \multicolumn{2}{|c|}{ Groups } & \multirow[b]{2}{*}{$P$ Value } \\
\hline & 1 & 2 & \\
\hline Female & $88 \%$ & $64 \%$ & 0.047 \\
\hline Age & $46.8 \pm 12.1$ & $39.1 \pm 10.7$ & 0.02 \\
\hline Heartburn & $9.1 \pm 8.5$ & $7.6 \pm 6.8$ & $0.51 \mathrm{NS}$ \\
\hline LES & $11.6 \pm 5.2$ & $14.0 \pm 6.2$ & $0.14 \mathrm{NS}$ \\
\hline UES & $58.4 \pm 15.9$ & $69.5 \pm 30.7$ & $0.11 \mathrm{NS}$ \\
\hline De Meester index & $34.0 \pm 20.9$ & $15.4 \pm 9.4$ & $<0.001$ \\
\hline \multicolumn{4}{|l|}{ Distal probe } \\
\hline Number of reflux & $43.0 \pm 20.4$ & $26.4 \pm 17.2$ & $<0.003$ \\
\hline$\%$ time $\mathrm{pH}<4$ & $9.0 \pm 6.4$ & $3.4 \pm 2.1$ & $<0.001$ \\
\hline \multicolumn{4}{|l|}{ Proximal probe } \\
\hline Number reflux & $7.5 \pm 10.9$ & $5.3 \pm 5.7$ & $0.38 \mathrm{NS}$ \\
\hline$\%$ time $\mathrm{pH}<4$ & $1.2 \pm 2.7$ & $0.5 \pm 0.7$ & $0.21 \mathrm{NS}$ \\
\hline
\end{tabular}

LES $=$ lower esophageal sphincter

$\mathrm{UES}=$ upper esophageal sphincter 
disturbance in either group. The contraction amplitude in the distal third of the esophagus was $69.5 \pm 25.7 \mathrm{~mm} \mathrm{Hg}$ in voice disturbance patients and $70.0 \pm 29.2 \mathrm{~mm} \mathrm{Hg}(P=0.94)$ in the controls (Table 2).

The prolonged esophageal $\mathrm{pHmetry}$ revealed that the De Meester index among dysphonia patients $(34.0 \pm 20.9)$ was higher than among controls $(15.4 \pm 9.4 ; P<0.001)$. A similar result was found concerning the number of acid reflux episodes in the distal probe, being $43.0 \pm 20.4$ in the individuals with dysphonia and $26.4 \pm 17.2$ in the controls $(P<0.003)$. The distal probe also showed that the percentage of time in which the esophageal $\mathrm{pH}$ values were lower than 4 units was greater among patients with dysphonia $(9.0 \% \pm 6.4 \%)$ than among controls $(3.4 \% \pm 2.1 \%)$, with significant difference $(P<0.001)$. The proximal probe did not show significant differences. The number of reflux episodes in G1 patients was $7.5 \pm 10.9$ versus $5.3 \pm 5.7$ in the controls $(P=0.38)$. Time percentage with esophageal $\mathrm{pH}$ below 4 units was $1.2 \pm 2.7$ in G1 and $0.5 \pm 0.7$ in the controls $(P=0.21)$ (Table 2$)$.

Videolaryngoscopy revealed alterations in the vocal folds in the majority of patients. The most common modifications were: congestion, atrophy, asymmetry, nodules, cysts, and polyps. Pachydermia and edema in arytenoids were other disturbances evaluated by this exam (Table 1; Figures 1, 2 and 3).

\section{DISCUSSION}

In this retrospective study the clinical, manometric and $\mathrm{pHmetric}$ aspects of the esophagus were evaluated in patients with GERD and dysphonia (G1) examined from January 2007 to December 2009. The findings were compared with the same parameters evaluated in chronic refluxers without voice disturbance (G2 - controls).

Group 1 patients were, at first, attended in the voice disturbance ward and then sent, as a routine practice, for gastroenterologic evaluation as they complained of pyrosis associated with hoarseness and voice failure.

Larynx direct exam showed lesions in the vocal folds (congestion, nodules, polyps) besides pakidermia and edema interarytenoideus, typical of reflux laryngitis ${ }^{(1,21,29)}$.

Hicks et al. ${ }^{(8)}$ carried out larynx endoscopic investigations of 105 normal volunteers and observed alterations on larynx in $86 \%$ of the casuistic. But, these authors did not exclude of the study, individuals using alcohol and tobacco, both factors that can cause lesions on laryn $x^{(18,22,32)}$.

Female patients were more numerous among refluxers with dysphonia than in the control group $(P=0.047)$, as found by several authors ${ }^{(2,14,18,30)}$.

Patients with dysphonia were older $(46.8 \pm 12.1$ years $)$ than the controls $(39.1 \pm 10.7$ years; $P=0.02)$, suggesting a longer time of aggression to larynx epithelium. However, statistical analysis showed no difference $(P=0.51)$ in relation to pyrosis duration between the two groups $(9.1 \pm 8.5$ years and $7.6 \pm 6.8$ years).

Digestive endoscopy revealed that most of the patients with dysphonia (95\%) did not present lesions in the esophageal epithelium (non-erosive reflux disease), corroborating other authors ${ }^{(13,31)}$. Hiatal hernia, an important GERD pathogenic factor, was diagnosed in $65 \%$ of G1 patients and in $60 \%$ of G2 $(P=0.77)$, as also observed by Loffeld and Putten ${ }^{(16)}$. According to Koufman et al. ${ }^{(13)}$, endoscopy is an excellent method to evaluate the esophagus. However, it is not the exam of choice for diagnosing laryngopharyngeal reflux. Our results are similar to findings of some other authors ${ }^{(14,16)}$.

Esophageal motor activity revealed that LES average pressure did not differ between patients with dysphonia and controls. These values were similar to the ones observed by Montenovo et al. ${ }^{(19)}$ and Fouad et al. ${ }^{(5)}$. Somani et al. ${ }^{(27)}$ reported a negative correlation between LES amplitude pressure and the esophagitis degree. According to these authors, non-erosive reflux disease individuals did not present hypotensive LES, as observed in the present study.

Knight et al. ${ }^{(11)}$ studied 112 GERD patients with extraesophageal manifestations. Hoarseness was the most prevalent as in the present casuistic. These authors reported esophageal dysmotility in $48 \%$ of patients with hoarseness. This finding differed from our casuistic in which the pressure amplitude in the distal third of the esophagus was $58.4 \pm 15.9 \mathrm{~mm} \mathrm{Hg}$ in dysphonic patients and none of them presented amplitude below $30 \mathrm{~mm} \mathrm{Hg}$ in this esophageal segment (inefficient esophageal motility). This disagreement among findings might be related to exam methodology since the previous authors used a solid state pressure transducer, whereas we used a catheter with continuous infusion for the manometric study. In G2 patients, pressure amplitude in the esophageal distal third was of $70+29.2 \mathrm{~mm} \mathrm{Hg}$, which does not differ from that of $\mathrm{G} 1(P=0.94)$.

Pressure measurement in the UES did not differ from the one observed in the control group, with values similar to those published by Lemme et al. ${ }^{(15)}$, who measured normal individuals. Given our expectation of finding lower indexes, it was surprising to find normal pressure values in individuals with hoarseness. In this situation, the refluxed content from the stomach would reach the larynx more easily, although no research shows this fact.

The results concerning the esophageal motor activity in the present study were similar to those of Shaker et al. ${ }^{(26)}$ and $\mathrm{Katz}^{(10)}$.

Pathologic gastroesophageal reflux was demonstrated by prolonged esophageal pHmetry in $88 \%$ of GERD patients with dysphonia, similar to levels found by other researchers ${ }^{(17}$, ${ }^{31}$. In the control group (without dysphonia), the exam positivity was $56 \%$. In G1 patients, the De Meester index was higher than that observed in the control group $(P<0.001)$. The number of reflux episodes and percentage of time with $\mathrm{pH}$ lower than four units in the distal probe, was higher in the group of dysphonic patients than among the chronic refluxers without voice disturbance $(P<0.003$ and $P<0.001$, respectively).

The seriousness of the gastroesophageal reflux explains the absence of clinical response when patients with dysphonia were submitted to the classic therapy with proton pump inhibitors. We observe that remission of symptoms occurs only after long-term treatment ( 8 weeks) administered twice a day. 
No significant difference was observed between the groups as to $\mathrm{pHmetric}$ parameters recorded in the proximal probe $(P=0.38$ for the number of reflux episodes and $P=0.21$ for percentage of time with $\mathrm{pH}$ lower than 4 units). This result was not expected and no plausible explanation was found.

Of the $25 \mathrm{G} 1$ patients studied, 10 actively use the voice because they are teachers. It is likely that GERD and voice abuse constituted a synergic cause, producing voice disturbance.
The conclusions of the present study are:

a) The clinical, endoscopic, and manometric findings observed in the patients with voice disturbance do not differ from those without these symptoms.

b) Gastroesophageal reflux is more serious in patients with dysphonia.

c) Patients without vocal disturbance can also present reflux episodes in the proximal probe.

Henry MACA, Martins RHG, Lerco MM, Carvalho LR, Lamônica-Garcia VC. Doença do refluxo gastroesofágico e distúrbios da voz. Arq Gastroenterol. 2011;48(2):98-103.

RESUMO - Contexto - A doença do refluxo gastroesofágico (DRGE) é uma doença crônica na qual o conteúdo gastroduodenal reflui para o esôfago. O quadro clínico da DRGE é usualmente referido como pirose e regurgitação (manifestações típicas). Manifestações atípicas (distúrbios da voz e asma) podem também ser referidas. Objetivo - Analisar os aspectos clínicos, endoscópicos, manométricos e pHmétricos de pacientes portadores da DRGE com distúrbios da voz. Método - Foram estudados 50 pacientes com a DRGE, sendo 25 com distúrbios da voz (grupo 1 - G1) e 25 sem estes sintomas (controles, grupo 2 - G2). Todos os pacientes foram submetidos a endoscopia, manometria e pHmetria esofágica (dois sensores). Os pacientes do G1 foram submetidos a videolaringoscopia. Resultados - Achados endoscópicos: DRGE não-erosiva foi observada em $95 \%$ dos pacientes de G1 e em $88 \%$ de G2. Videolaringoscopia: congestão das pregas vocais, assimetria, nódulos e pólipos foram diagnosticados nos pacientes do G1. Manometria esofágica: pressão no esfíncter inferior do esôfago (mm Hg): 11,6 $\pm 5,2$ em G1 e 14,0 \pm 6,2 em G2 $(P=0,14)$; pressão no esfíncter superior do esôfago (mm Hg): 58,4 \pm 15,9 em G1 e 69,5 $\pm 30,7$ nos controles. Achados pHmétricos: índice de DeMeester: 34,0 $\pm 20,9$ em G1 e 15,4 $\pm 9,4$ em G2 ( $P<0,001)$; número de episódios de refluxo no sensor distal: 43,0 $\pm 20,4$ em G1 e 26, $4 \pm 17,2$ em G2 $(P<0,003)$; percentagem do tempo com pH esofágico menor que 4 unidades (sensor distal): 9,0\% $\pm 6,4 \%$ em G1 e 3,4\% $\pm 2,1 \%$ em G2 $(P<0,001$ ); número de episódios de refluxo no sensor proximal: 7,5 $\pm 10,9$ em G1 e 5,3 $\pm 5,7$ em G2 $(P=0,38)$; percentagem de tempo com pH esofágico menor que quatro unidades (sensor proximal): $1,2 \% \pm 2,7 \%$ em G1 e 0,5\% $\pm 0,7 \%$ em G2 $(P=0,210)$. Conclusões - Os aspectos clínicos, endoscópicos e manométricos em pacientes com a DRGE e distúrbios da voz não diferem dos pacientes sem estes sintomas. A intensidade do refluxo gastroesofágico é maior nos pacientes com distúrbios da voz. Os pacientes sem distúrbios da voz podem também apresentar episódios de refluxo gastroesofágico no sensor proximal.

DESCRITORES - Refluxo gastroesofágico. Distúrbios da voz.

\section{REFERENCES}

1. Carr M, Nguyen A, Poje C, Pizzuto M, Nagy M, Brodsky L. Correlation of findings on direct laryngoscopy and bronchoscopy with presence of extraesophageal reflux disease. Laryngoscope. 2000;110:1560-2.

2. Cervantes O, Abrahão M. O nódulo vocal - conceitos atuais. RBM Rev Bras Med. 1995;11:12-7.

3. Cherry J, Margulies SI. Contact ulcers of larynx. Laryngoscope. 1968;78: 1937-40.

4. Cuenca-Abente F, Faerberg A, Fernández Marty P, Corti R. Sintomas respiratorios asociados a da enfermedad por reflujo gastroesofágico: diagnóstico y tratamiento. Acta Gastroenterol Latinoam. 2006;36:42-50.

5. Fouad YM, Katz PO, Hatlebakk JG, Castell DO. Ineffective esophageal motility: the most common motility abnormality in patients with GERD - associated respiratory symptoms. Am J Gastroenterol. 1999;94:1464-7.

6. Henry MA. [Continuous evaluation of esophageal $\mathrm{pH}$ for 24 hours and its use in the diagnosis of gastroesophageal reflux]. Rev. Hosp Clin Fac Med São Paulo. 1984;39:203-7.

7. Henry MA, Habermann MC, Rocha OM. Esophageal motor disturbances in progressive systemic sclerosis. Dis Esophagus. 1999;12:51-3.

8. Hicks DM, Ours TM, Abelson TI, Vaezi MF, Richter JE. The prevalence of hypopharynx findings associated with gastroesophageal reflux in normal volunteers. J Voice. 2002,16:564-79.

9. Jacob P, Kahrilas PJ, Herzon G. Proximal esophageal pHmetry in patients with 'reflux laryngitis'. Gastroenterology. 1991;100;305-10.

10. Katz PO. Ambulatory esophageal and hypopharyngeal $\mathrm{pH}$ monitoring in patients with hoarseness. Am J Gastroenterol. 1990;85:38-40.

11. Knight RE, Wells JR, Parrish RS. Esophageal dysmotility as an important cofactor in extraesophageal manifestations of gastroesophageal reflux. Laryngoscope. 2000;110:1462-6.

12. Koufman JA, Wiener GJ, Wu WC, Castell DO. Reflux laryngitis and its sequela: the diagnostic role of ambulatory 24-hour monitoring. J Voice. 1988;2:78-9.
13. Koufman JA. Laryngopharyngeal reflux is different from classic gastroesophageal reflux disease. Ear nose Throat J. 2002;81:1-5.

14. Koufman JA, Belafsky PC, Bach KK, Daniel E, Postma GN. Prevalence of esophagitis in patients with $\mathrm{pH}$ - documented laryngopharyngeal reflux. Laryngoscope. 2002;112:1606-9.

15. Lemme EMO, Domingues GR, Silva LFD, Firman CG, Pantoja JAS Esofagomanometria computadorizada: resultados preliminares em voluntários adultos saudáveis. GED Gastroenterol Endoscop Dig. 2001;20:29-35.

16. Loffeld RJ, van der Putten AB. Rising incidence of reflux oesophagitis in patients undergoing upper gastrointestinal endoscopy. Digestion. 2003;68:141-4.

17. Marambaia O, Andrade NA, Varela DG, Juneal MC. Refluxo laringofaríngeo: estudo prospectivo correlacionando achados laringoscópicos precoces com a pHmanometria de 24 horas de 2 canais. Rev Bras Otorrinolaringol. 2002;68:81-5.

18. Martins RHG. Aspectos anatômicos e fisiológicos da laringe. In: A voz e seus distúrbios. Botucatu: Cultura Acadêmica, 2005. p.15-30.

19. Montenovo M, Tatum RP, Figueredo E, Martin AV, Vu H, Quiroga E, Pellegrini CA, Oelschlager BK. Does combined multichannel intraluminal esophageal impedance and manometry predict postoperative dysphagia after laparoscopic Nissen fundoplication? Dis Esophagus. 2009;22:656-63.

20. Moraes-Filho J, Cecconello I, Gama-Rodrigues JJ, Castro L, Henry MA, Meneghelli UG, Quigley E. Brazilian consensus on gastroesophageal reflux disease: proposal for assesment, classification and management. Am J Gastroenterol. 2002;97:241-8.

21. Nishimura K, Fujita H, Tanaka T, Tanaka Y, Matono S, Murata K, Umeno $\mathrm{H}$, Shirouzu K. Endoscopic classification for reflux pharyngolaryngitis. Dis Esophagus. 2010;23:20-6.

22. Ozturk O, Oz F, Karakullukcu B, Oghan F, Guclu E, Ada M. Hoarseness and laryngopharyngeal reflux: a cause and effect relationship or coincidence? Eur Arch Otorhinolaryngol. 2006;263:935-9.

23. Potluri S, Friedenberg F, Parkman HP, Chang A, MacNeal R, Manus C, Bromer MQ, Malik A, Fisher RS, Nugent T, Thangada VK, Kueppers F, Miller LS. Comparison of salivary / sputum pepsin assay with 24-hour esophageal $\mathrm{pH}$ monitoring for detection of gastric reflux into the proximal esophagus, oropharynx and lung. Dig Dis Sci. 2003;48: 1813-7. 
24. Richter JE. Ear, nose and throat and respiratory manifestations of gastroesophageal reflux disease: an increasing conundrum. Eur J Gastroenterol Hepatol. 2004; 16:837-45.

25. Savary M, Miller G. The esophagus. handbook and atlas of endoscopy. Solothurn: Verlag Gassmann; 1978.

26. Shaker R, Milbrath M, Ren J, Toohill R, Hogan WJ, Li Q, Hofmann CL. Esophagopharyngeal distribution of reflux and gastric acid in patients with reflux laryngitis. Gastroenterology. 1995;109:1575-82.

27. Somani SK, Ghoshal VC, Saraswat VA, Aggarwal R, Misra A, Krishnanai N, Naik SR. Correlation of esophageal $\mathrm{pH}$ and motor abnormalities with endoscopic severity of reflux esophagitis. Dis Esophagus. 2004;17:58-62.

28. Vaezi MF, Hicks DM, Abelson TI, Richter JE. Laryngeal signs and symptoms and gastroesophageal reflux disease (GERD): a critical assessment of cause and effect association. Clin Gastroenterol Hepatol. 2003;1:333-44.
29. Vaezi MF. Are there specific laryngeal sign for gastroesophageal reflux disease? Am J Gastroenterol. 2007;102:723-4.

30. Vashani K, Murugesh M, Hattiangadi G, Gore G, Kerr V, Ranesh VS, Sandur $\mathrm{V}$, Bhatia SJ. Effectiveness of voice therapy in reflux-related voice disorders. Dis Esophagus. 2010;23:27-32.

31. Wiener GJ, Koufman JA, Wu WC, Cooper JB, Richter JE, Castell DO. Chronic hoarseness secondary to gastroesophageal reflux disease: documentation with 24-hour ambulatory pH monitoring. Am J Gastroenterol. 1989;84:1503-8.

32. Wong RKH, Hanson DG, Warring PJ, Shaw G. ENT manifestations of gastroesophageal reflux. Am J Gastroenterol. 2000;95:S15-22.

Received 17/8/2010 Accepted 20/10/2010 